\title{
How do Restructuring Processes Influence Low- and Unskilled Immigrant and Nonimmigrant Workers and their Managers in a Norwegian Hospital?
}

\section{Heidi Enehaug'}

Senior Researcher, Work Research Institute, Oslo and Akershus University College of Applied Sciences, Norway

\section{Svenn-Erik Mamelund}

Senior Researcher, Work Research Institute, Oslo and Akershus University College of Applied Sciences, Norway

\begin{abstract}
It is a well-known fact that workplace restructuring has undesirable effects on the psychosocial work environment, health, and sick leave, but no attention has been given to the health effects of work environments characterized by restructuring, a multicultural staff, and a strong socioeconomic occupational hierarchy. In this casestudy, we examine a large Nonwegian hospital in which all of these features are present. Through in-depth interviews with employees and their managers we investigate the healthiness of the restructuring process, and the consequences of the restructuring process on the work environment, subjective health, and sick leave. Results show that immigrant workers received less information, had higher level of frustration and less control over work, and experienced a decrease in well-being, autonomy, and social support. Immigrant worker vulnerability, that is, the handicap of poor understanding of the Norwegian language and a lack of understanding of general and local organizational norms and practices in the Norwegian workplace, is an important explanation. Immigrant workers with a poor Nonwegian language understanding are even worse off. We conclude that a strong occupational hierarchy within the hospital exerts an overall influence on the position of low/unskilled employees in the restructuring process as well as their perception of and involvement in it.
\end{abstract}

\section{KEY WORDS}

Change / Health sector / Immigrant workers / Low-lunskilled workers / Public sector / Restructuring I Sickness absence / Work environment

\section{Introduction}

vast amount of international research has documented that workplace restructuring, and mergers and acquisitions can have undesirable effects on the psychosocial work environment, individual health, and sick leave listing (see reviews in, e.g., Bambra et al., 2007; Egan et al., 2007; Enehaug and Thune, 2007), and several have studied the relationship between these factors among medical staff at hospitals (Bernstrøm, 2014; Burke, 2002; Mamelund et al., 2014). Prior research has also documented that low and unskilled workers and immigrants are at a higher risk of experiencing negative health

\footnotetext{
1 Heidi Enehaug, Work Research Institute, Oslo and Akershus University College of Applied Sciences, Box 4, St
} Olavs plass, 0130 Oslo, Norway. E-mail: heidi.enehaug@hioa.no 
consequences of restructuring than nonimmigrants and higher socioeconomic status groups. One reason for this may be that low and unskilled workers and immigrants may be more prone than nonimmigrants and higher skilled workers to apply for-and remain in-jobs where there is a higher risk of reorganization. Furthermore, they often tend to hold jobs where the risk of detrimental health consequences because of restructuring is higher (selection). Another reason may be that the lower socioeconomic status group for various reasons may be less able to cope with the stress associated with restructuring-that may lead to ill health-than the higher socioeconomic status group (causation) (Gamperiene, 2008). Prior studies have indicated that poor Norwegian language skills among immigrants may be an additional risk factor for adverse health effects associated with reorganizations (see, e.g., Enehaug, 2008; Enehaug and Widding, 2011, 2013). However, no attention has been given to the adverse health effects of work environments characterized by a climate of constant restructuring, a multicultural staff, and a strong socioeconomic occupational hierarchy. Here we study a large Norwegian hospital that displays all of these features. We use a case-study approach to analyze qualitative interview data with 23 workers and 7 managers coming from three nonmedical departments at the hospital.

The aim of the present paper is twofold: First, we examine the restructuring process among low/unskilled workers and their managers at a large Norwegian hospital in Norway, and study whether these experiences are different for immigrant workers than for nonimmigrant workers. We also study whether potential differences can be explained by poor knowledge of the Norwegian language among the immigrants, and to what extent language skills may influence the experience of the restructuring itself. By doing this we extend prior literature by studying other occupational groups working at a hospital than highly skilled doctors and nurses. Second, we investigate how the restructuring processes affect the work environment, subjective health, and sickness absence of these groups. Our qualitative data will not allow a disentangling of effects of selection from effects of causation. Based on prior studies of restructuring and health, and studies of immigrant workers' work environment, we hypothesize that work environment variables such as social support, participation, and control over work, manager availability, and communication issues may be seen as indicators of a healthy restructuring process. For analytical purposes we have included additional factors from research which documented that awareness among managers of diversity, local norms, availability, constructive conflicts, and early role clarification is important in order to create healthy organizational change processes (Saksvik and Finne, 2009; Saksvik et al., 2007).

This paper is structured in the following way. First, we present prior research on three fronts: 1) reorganizations and health outcomes; 2 ) indicators of a healthy restructuring process; 3 ) employment status and the work environment of immigrants and lowskilled workers in the Norwegian labor market. In the second part, we present our data and methods. We finally present and analyze the results before we conclude.

\section{Prior Studies}

\section{Reorganizations and health outcomes}

Research on organizational change often emphasizes the distinction between the content, the process, and the context and outcome variables (Armenakis and Bedeian, 1999), but it is also mentioned that these factors need to be seen in connection with 
each other (Self et al., 2007). The lack of success in many projects of organizational change and the subsequent threat to occupational health may be due to an underestimation of the significance of the quality of the organizational change process (Balzer et al., 2011; Dahl-Jørgensen and Saksvik, 2005; Nytrø et al., 2000; Saksvik et al., 2002). Employee involvement, employee readiness, and sufficient information about the alleged components of the change process, along with the attitude and actions of line managers and their intervention history have all been recorded to have positive effects on the outcome of the process of structural change, reducing stress, for example, and increasing job satisfaction, commitment, self-efficacy, well-being, and the intention to remain (Randall et al., 2009; Schweiger and DeNisi, 1991). Other studies pinpoint active involvement in the process and a good structure as key factors in an attempt to balance feelings of uncertainty during periods of organizational change (Balzer et al., 2011).

Consequences of workplace restructuring and mergers and acquisitions include adverse changes in demands (Kivimäki et al., 2000), loss of control (Kivimäki et al., 2000; Proctor and Dukakis, 2003; Worrall and Cooper, 1998), and changes in the relations between employees, for example, a decrease in social support (Kivimäki et al., 2003). These changes in the psychosocial work environment may in turn contribute to increased job strain or stress (Kivimäki et al., 2003; Korunka et al., 2003), job insecurity (DeWitte, 1999), undesirable subjective health and sick leave (see, e.g., Bambra et al., 2007; Egan et al., 2007; Enehaug and Thune, 2007). A public sector study (Trygstad, 2006) showed that there are significant differences in perceived work strain between employees that have experienced restructuring and those that have not, and Noer (1993) introduced the concept of "lay-off-survivor-syndrome" to describe what happens to those who remain after downsizing processes. Some research results have also suggested the opposite: that those who lose their jobs (the victims) may in fact be better off in some ways than those who remain (the survivors), reversing the commonly held view about who are the victims and who are the survivors (Burke, 2002).

A recent paper studying 50 Norwegian hospitals found that employee groups with lower education had the highest sickness leave rates following various levels of restructuring (Mamelund et al., 2014). It is plausible that these groups experience a higher work demand and less autonomy during reorganization than groups with higher education (e.g., doctors and nurses), and that they are more vulnerable and likely to make use of sick leaves.

\section{Indicators of the healthiness of the restructuring process}

Saksvik and colleagues have found that five dimensions are important for the healthiness of organizational change processes (Saksvik and Finne, 2009; Saksvik et al., 2007). We have sought inspiration from these five dimensions in our analysis:

1. Awareness of diversity. Employees may react in various ways to organizational changes both as individuals and as groups or units in the organization. It is important to capture the diversity of the organization, and not only concentrate on the stories of key people. Thus, awareness of diversity is related positively to a healthy process, both by creating an environment of openness and trust, and by facilitating manager understanding of employees undergoing change. 
2. Awareness of local norms. The organization's norms are perceptions and explanations regarding "how we do it." The local standards are important for what is considered acceptable and not acceptable attitudes in the organization, and they help set standards for the change processes. To achieve a healthy restructuring process it is essential to be aware of current standards and continue to evaluate them together.

3. Manager availability. Managers must be available and actively present in the reorganization process. The need for information increases, and employees have the opportunity to ask questions of the management about their own situation, even in an informal way and at their own initiative, and to receive regular, specific, and credible information in return. Opportunities for dialogue with one's superior can help to reduce uncertainty and stress. Being present also increases the ability of managers to understand how people experience the transition.

4. Constructive conflicts. In constructive conflict management, all employee reactions are considered seriously. Resistance is not necessarily a result of poorly managed change implementation; it is merely an expected human response. If this resistance is brushed aside as being "irrational," it can make bad matters worse. A sense of active participation and the acceptance of expressing one's views confer a feeling of control and influence, and lessen the chances of feeling victimized and ignored during the change process.

5. Early role clarification. Early role clarification reduces role stress by reducing role ambiguity and role conflict. Early role clarification is important because the consequences of role stress may be destructive for the change initiative, for the work group, and for the individual worker (all dimension descriptions derived from Saksvik and Finne, 2009; Saksvik et al., 2007).

\section{Immigrants and low-skilled workers in the Norwegian labor market}

Studies of the immigrants' situation in the Norwegian labor market during the 1990s focused on integration and on the cultural aspect of the workplaces (Berg, 2000; Berg et al., 1999; Håpnes and Iversen, 2000; Johansen and Østby, 1998; Rogstad, 1998, 2000; Rogstad and Raaum, 1997). Later studies, among them studies analyzing the health and the industrial sectors, have shown that poor language skills among immigrant employees contribute to work environment problems, due to poor understanding of health, environment, and safety issues and a management style characterized by "less is more communication" and further distancing strategies (Enehaug, 2008; Enehaug and Widding, 2011, 2013).

Recent studies also indicate that being an immigrant worker may increase one's "vulnerability"(Enehaug and Widding, 2011), meaning that less access to social support systems, information, and management may influence the individual's ability to be proactive and protective with regard to his or her own interests. It has been highlighted that immigrant workers themselves display a lack of workplace knowledge and that segregation and group encapsulation will be an ongoing problem for immigrant workers as long as government policies and employers do not address this issue (Farsethås et al., 2011, pp. 79-80). One study has also shown that poor manager availability generated a higher risk of mental health problems for unskilled female immigrants than for unskilled females of Norwegian majority origin (Gamperiene, 2008). 
Compared to ethnic Norwegian laborers in the food and beverage industry, migrant laborers in the same industries have been found to have significantly higher job stress and mental health problems (Saksvik et al., 2010). Compared with ethnic Norwegians in the food and beverage industry, migrant Polish laborers in the construction and cleaning industries also have higher work stress, but not more mental health problems (Saksvik et al., 2013). In the two latter studies, the personal ambitions of the immigrants, measured in terms of a higher level of overcommitment compared with the ethnic Norwegians, played an important role in explaining the ethnic differences in job stress and mental health. Although employment rates are generally high and unemployment rates are low in Norway, there are nevertheless marked ethnic differences in how these outcomes play out. Studies show that immigrant workers on average are more likely to be unemployed than ethnic Norwegian workers, but also that immigrants have more trouble getting a new job after a period of unemployment than nonimmigrants (see, e.g., Grambo and Myklebø, 2010).

\section{Data and Methods}

\section{Study setting}

The study was carried out at a Norwegian hospital that provides health care services to approximately half a million inhabitants. The hospital is among the largest in Norway. Main activities include research and education in addition to somatic and mental health services. The hospital had half a million patient contacts in 2012. The hospital has been undergoing major restructuring since 2005, partly to prepare for moving into a new building and it has also been merged with several smaller hospital units. Restructuring was still going on during the data collection period.

\section{Study design}

Our study has a qualitative research design (Marshall and Rossman, 1989; Patton, 1990, 2002) based on a mix between a general interview guide approach and a standardized open-ended interview (Patton, 2002). This kind of design has also been labeled pragmatic qualitative research (Savin-Baden and Major, 2013). This design gave us as researchers flexibility in "probing and in determining when it is appropriate to explore certain subjects in greater depth, or even to pose questions about new areas of inquiry that were not originally anticipated" (Patton, 2002, p. 347). This flexibility was important because some of our informants had poor Norwegian language skills. On several occasions, we had to expand the expected interview length in order to secure a trustful environment and to have time to rephrase questions in order to obtain useful information. Because of this, the interviews had a dialogue-oriented approach, or what has been labeled inter views in the literature (Kvale and Brinkmann, 2009). Equating or modeling in-depth interviews so that they were more as everyday conversations increased the opportunities for openness. Sometimes "ice-breakers" in establishing this kind of relationship occurred when we referred to other work organizations' practices, cultures, leadership, experiences, and so forth. The act of “mirroring" the informants' statements (in the attempt to obtain a deeper understanding), similar to what Patton (2002) calls providing 
reinforcement and feedback by taking the informant's point of views, sometimes resulted in a more trustful relationship. The informants were encouraged to ask critical questions, to challenge the underlying premises of the situation. The usefulness of this strategy was not necessarily dependent on the informants' organizational role or their educational status, but was attributable more to the interview setting in itself. Low-skilled employees may have more issues to address and questions to ask, perhaps because they do not take the situation "for granted," that is, they enter the situation without any prior notions of what to expect. Managers or other highly skilled/educated employees sometimes displayed different expectations concerning their own role as informants-they seemed to perceive themselves largely as "field experts."

\section{Interviews}

We carried out a total of 21 individual and 4 group interviews, covering 30 informants. Informants could choose to participate in a group interview instead of individual interviews if they expressed any concern about the situation. Nine employees from the cleaning department preferred to do a group interview. We ended up doing four group interviews for practical reasons. The characteristics of the nine informants in each interview group are described in Table 1.

Our interview guide included themes such as occupational history and present work situation, changes in work situation due to restructuring, work environment, mastery and meaning in work, the perception of the restructuring processes, the role of management, subjective health, and sickness absence history.

Table I Group interviews by number of informants, ethnicity, and language skills

\begin{tabular}{llll}
\hline & Number of informants & Ethnicity & Language skills \\
\hline Group 1 & 3 & Immigrant, immigrant, immigrant & Poor, poor, good \\
\hline Group 2 & 2 & Immigrant, ethnic Norwegian & Good, good \\
\hline Group 3 & 2 & Immigrant, immigrant & Poor, poor \\
\hline Group 4 & 2 & Immigrant, ethnic Norwegian & Good, good \\
\hline
\end{tabular}

\section{Selection of informants}

We asked the hospital to provide us with 10 employees and managers coming from each of the three departments of (1) cleaning, (2) administration \& security, and (3) canteen, giving us 30 informants in total. Within each department, we further asked for an equal distribution of immigrant/nonimmigrant respondents and respondents who had taken out long-term sickness absence/short-term sickness absence over the course of the last year. As it turned out, the hospital was unable to provide informants with the desired characteristics and we had to settle for an uneven distribution of informants from the various departments (see distributions in next paragraph, the sample characteristics). This means that the use of departmental affiliation has interest mainly in terms of work tasks. We coded informants as immigrants using Statistics Norway's definition. An immi- 
grant according to this definition is a person who has two foreign-born parents and has himself immigrated to Norway. We did not develop an appropriate instrument to measure the variation in the Norwegian skills and language understanding of immigrants. It is therefore important to stress that not all immigrant workers in our sample had poor Norwegian language skills.

\section{Sample characteristics}

We carried out interviews with the 30 informants two to three years after the hospital had moved into their new premises.

Of the informants, 7 were managers and 23 were employees. A little more than half of the respondents were immigrants (16 persons). The age distribution was relatively even between age groups; seven persons were aged $20-30$ years, six persons were aged $30-40$ years, nine were aged 40-50 years, and eight persons were 50-60 years old. Nineteen of the 30 interviewees were employed in the cleaning department, six in the canteen and five in the department of security and administration. Gender was not registered. Six out of seven managers were lower level managers and one was a departmental manager.

We have not tested the immigrants' Norwegian language skills and understanding objectively. However, we subjectively assessed that one out of two immigrants have poor language skills ( 8 out of 16 immigrants).

A total of $17 \%$ (5 out of 30 ) of the informants had been on long-term sickness absence during the last year before the interview, while $53 \%$ (16 persons) had one or more periods of short-term sickness absence. This means that 7 out of 10 had been on one or the other form of sick leave during the last year before the interview. Our material cannot say anything about differences in sick leave between departments because of the uneven departmental distribution of informants. Five out of 19 informants from the cleaning department had no sickness absence during the past year.

\section{Data analysis}

The interviews lasted for approximately 1.5 hours and were recorded and transcribed. The analysis proceeded in three steps and was based on a case-study approach (see one example in Figure 1). First the interviews were analyzed through margin notes and open coding to gain an overview of the content (Creswell, 2013; Patton, 2002). Second, the NVIVO 9 data program was used to develop broader categories or themes based on the codes from the first phase and on discussions and revisions executed by the two researchers performing the interviews. Third, the categories were fitted into a matrix of main analytic categories and sorted by the most relevant background variables to search for potential patterns. The main analytic categories were a mix of Saksvik and colleagues' $(2007,2009)$ indicators of the healthiness of a restructuring process and the more classic work environment factors: social support, manager availability, participation and control over work, perception of the restructuring process, awareness of local norms, and early role clarification. In addition, we also analyzed the possible effects of restructuring on 1) time pressure, workload, and work environment; 2) subjective heath and self-reported reasons for sick leave. The chosen background variables were 
Figure I: Example of analysis process from quote to margin notes/simple coding, broader category and main analytic category.

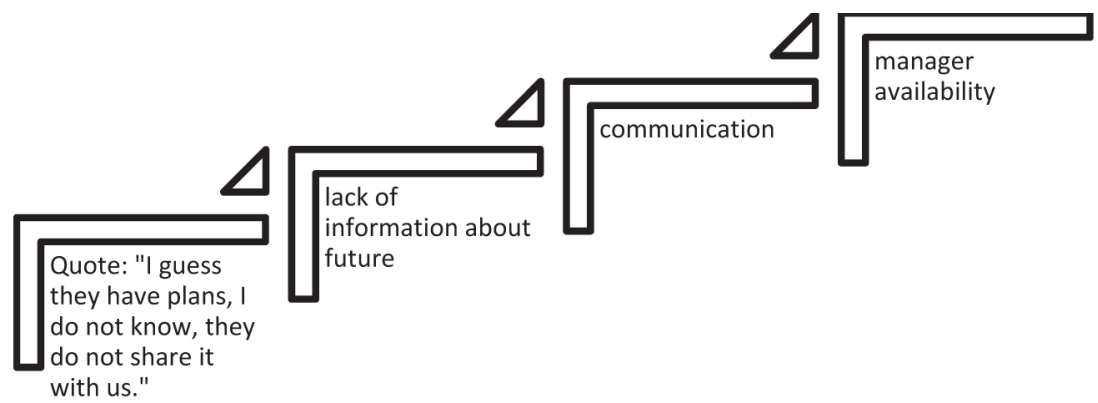

employee/manager, departmental affiliation (cleaning/security and administration/canteen), immigrant status (immigrant/nonimmigrant), language understanding (poor/ good), and period of sick leave (short term/long term).

The fact that 8 out of 16 immigrants had a poor understanding of the Norwegian language affected the quality of the interview data negatively. It proved difficult, and in some cases nearly impossible, to get input on the questions asked from this group of informants. We interpret this as a general illustration of the organization's diversity management problems and see that the study in this sense has some analytic limitations. By doing group interviews, we nevertheless had a chance to combine various levels of language skills, and gain a more thorough understanding through dialogues and translation efforts within the group. In this article, we have chosen to describe what the immigrant informants told us rather than use quotes that, outside the full interview transcript context, might be difficult to understand and which might put our informants in a bad light because of their difficulty in being able to formulate themselves clearly.

In this article the quotes used are marked with title and departmental affiliation: M (manager), E (employee), c (cleaning department), s\&a (security and administration), can (canteen). In addition each informant has a separate number-for example, Quote (M7, can, immigrant), meaning informant number 7 is a canteen manager categorized as an immigrant. Only one manager came from the laundry department (L).

\section{Ethical considerations}

The prospective informants were asked to participate in the study either by their manager or by the head of the Department of Health Promoting Work in the central administration of the hospital. The informants also received a letter informing them about the aim of the study, how it was to be carried out, and who was going to conduct it. Informed content was obtained. The Norwegian Social Science Data Services approved the study.

\section{Results and Analysis}

The results are presented in two parts. We first present the restructuring process as experienced by the workers and their managers in view of the following five dimensions: 
1) perception of the restructuring process, 2) awareness of local norms, 3) social support, 4) manager availability, participation and control over work, and 5) early role clarification. It should be noted that these categories are, to some extent, both in line with the works of Saksvik and colleagues $(2007,2009)$ and a supplement to their model. For example, the fourth category in our analysis is an extended version of the original, and consists of participation and control over work, in addition to manager availability in the original model. This is explained below. We have also included social support as a self-contained dimension because this came out as an especially important finding in our data. We have further excluded the dimensions awareness of diversity and constructive conflicts because we did not find any support for them in our empirical material. In the second part, we present the analysis showing to what extent the healthiness of the restructuring process has an impact on the work environment, subjective health, and sickness absence of our informants.

We commence this paragraph by illustrating how employees and their managers perceive the restructuring process differently.

\section{The perception of the restructuring process}

The perception of what the restructuring process is per se varies between workers and their managers, and between managers by department. These observed differences may be seen as partly in line with the findings of Schweiger and DeNisi (1991) and Randall et al., (2009). Further, we find that Balzer et al.'s (2011) analysis implies that a lack of involvement and a poor structure may enhance insecurity throughout the organization. This may have potential effects on the perception of the process in itself. There are no significant differences between immigrant and nonimmigrant workers regarding the perception of the restructuring process. There are two worker-manager differences. First, while the employees describe restructuring mainly as the moving process from the old to the new building-and the information about and performance of it - the management in the various departments perceived the restructuring as both the moving process and the restructuring of hospital services and work organization. Second, there are also some differences between the two groups in the perception of the time frame of the restructuring process. The management tended to regard the process as having started at an earlier point in time than the employees. Some of the employees are in a position to date exactly when they think the moving process started and ended, while others are unaware of when and how the process started and what the future holds. They regard it as unfinished at the time of the interview. This can be seen as the result of yet another merger process in the making, due to take place shortly after the data collection period:

The restructuring is very exciting, if you end up with something better. The managers got that result. Better locations. Nevertheless, there is of course more office work now, and more running around. One cannot be out there as much as one would like to! (M26, c, Norwegian)

There are also differences in the perception of the restructuring process between the managers in the three departments. This seems to be a result of whether they see the 
changes as a major or minor incident, and whether they feel they have had the necessary information during the process, and proximity to the decision makers. There is also some indication that the differences in perception between managers in the three departments may be explained by management style, and the degree to which all-round pressure is experienced.

\section{Awareness of local norms}

In Saksvik and colleagues' work $(2007,2009)$ the understanding of the organization's local norms and understandings of "how we do things" is an important aspect of the restructuring processes. Other research has emphasized the importance of sense of organizational identity (Ravasi and Schultz, 2006; Van Knippenberg et al., 2006; Whetten, 2006). Our analysis shows that a lack of understanding of Norwegian work life norms in general, what to expect from managers and colleagues in terms of support, and the extent to which one is expected to participate in the restructuring processes (local norms) made immigrant workers more vulnerable than other low and unskilled workers. Ethnic Norwegians displayed higher expectations toward their managers and had a more critical stance-and distance-to the restructuring process compared to immigrant workers in general. There was a tendency among ethnic Norwegians to ascribe fault with regard to the negative results of restructuring (e.g., the increase in work strain, and the way work was organized in "bothersome" ways) to poor management, especially top management. We see indications that immigrant employees perhaps were more self-critical—rather than being critical of management, they excused their own insufficient language understanding. Differing expectations regarding the content of work, and the ascribed significance of active participation seemingly varies between immigrant and nonimmigrant workers. The following quote captures these differences nicely:

The immigrants do as they are told. At least in the beginning. Most of them still do. They seem to think that you are the boss, you are supposed to do what you are told. Moreover, they are not the ones to raise their hands and ask questions or put demands forward at personnel meetings. On the other hand, if they do, it is only about day-to-day, ordinary things, while the Norwegians are perhaps more used to demanding things and use their rights. (M39, L, Norwegian)

In situations characterized by insufficient information and where employees had to read between the lines in order to interpret what was being said, the lack of knowledge about Norwegian working life seemed to deepen frustration. This is in line with the experimental study findings of Schweiger and DeNisi (1991), who found that poor information about a merger process created major dissatisfaction in the workers. Little opportunity to communicate with coworkers contributed further to insecurity and the experience of stress in our sample of workers.

Differences in the awareness of local norms and differences in the weighted importance of them seem substantial in the understanding of immigrant and nonimmigrant workers' adaption and behavior in the restructuring process. 


\section{Social support}

We have added social support as a self-contained dimension to Saksvik and colleagues' (2007, 2009) original dimensions of a healthy reorganization process. Social support was highlighted as an especially important aspect to consider in relation to stress and health outcomes in the demand-control-support model (DCS model) (Karasek and Theorell, 1990), a finding that has been validated later by several others (see, e.g., Llorens et al., 2006; Schabracq et al., 2003). In later research, Saksvik and colleagues (2010, p. 4) have hypothesized that:

(..) social support from colleagues and supervisors is of minor importance for immigrant workers because they are less integrated in the work environment, and therefore this model [the DCS-model] has modest relevance for the work identity of immigrant employees and the levels of work-related stress and health problems they experience.

Saksvik and colleagues (2013, p. 95) have further suggested that:

(..) immigrant workers are in a situation where they have to rely on their own resources more than the collective resources, and thus, are at a greater risk of experiencing negative stress and bad health if they perceive little support and respect in their work environment from their employer, boss or colleagues.

In our study, immigrant workers seem to experience less social support from colleagues and managers than nonimmigrant workers do. In a situation characterized by the implementation of new routines, an increase in workload, little contact with management, and an insufficient understanding of what is happening, the lack of social support is more often than not attributed to an increase in workload, time pressure, and conflicts. However, the situation was especially bad for the immigrant cleaners (and especially those with a poor understanding of the Norwegian language), mostly because they had less opportunity than before to socialize within their own language groups. This deprived them of a sense of companionship at work, and adversely influenced their opportunities for social support. We agree with Saksvik et al., $(2010,2013)$ in that access to social support resources of their own is probably very important for the immigrants. However, in a situation where the immigrants cannot even rely on social support resources of their own, the opportunity to receive collective social support of any size is indeed important. The immigrant cleaners were hindered admission to both types of social support, and were therefore extra vulnerable to stress and health problems in the wake of the reorganizational processes at the hospital.

Both immigrant and ethnic Norwegian cleaners reported that the ethnic composition of the workforce was challenging. The reason was supposedly communication problems due to language barriers or alleged racism: "Norwegians are often called racists, but they (i.e., the immigrants) are racists themselves! They hate each other! For example, you must never ask the Filipino and the Thai women to work together. They argue really hard! (E19, c, Norwegian)"

This again seemed to steer employees into group formation according to country of origin. The vast majority of our informants described coworkers by group characteristics 
rather than by individual personal traits. Statements such as "they are afraid to speak up for themselves" were not uncommon. There was mention that conflicts among groups of employees either escalated or became more visible due to the restructuring process.

After moving into the new hospital building, each cleaner got a larger area to clean than in the old hospital building. In combination with fewer informal meeting points (e.g., a tea kitchen), this reduced the opportunities for informal conversation and cooperation between coworkers. The cleaning staff therefore became more dependent on establishing contact and appropriate cooperation with the nurses and doctors for informal social contact during the workday. Despite some new vertical socializing due to the new and larger hospital building, both managers and employees emphasized that the hospital is a hierarchical organization characterized by social status differences between the health care professionals and the rest of the staff. This affects both the cleaners and the security $\&$ administration staff in various ways. Both groups of employees describe a lack of recognition for the work they perform, and even some of their managers tell a tale of low appreciation and understanding of the necessity of this kind of work. When asked about cooperation between the various groups of employees in the hospital, one manager answered the following:
I believe that this is depending on the person. Some places it is excellent. Other places there is no kind of communication whatsoever. I think this has to do with the cleaner... what kind of a person is she? What kind of language problems and what sense of language understanding do you have? Are you able to make a normal conversation, or not? More- over, how is the chemistry between the nurses? Do they have a boss who tells them to talk and behave nicely towards everyone, whether they are medically trained personnel or not? (M16, c, Norwegian)

The above quote illustrates several important issues, also raised by other managers and employees. Language barriers and cultural differences may account for negative work environment characteristics in that they boost the perception of a "them and us" mindset among immigrant workers and ethnic Norwegian workers and from managers toward immigrant workers. The fact that some immigrant workers seemed unable to communicate in the expected manner was perceived both as an individual problem and as a group characteristic. This may in turn have influenced the managers' sense of responsibility with respect to social support and accountability for the psychosocial work environment in general. When managers described problems in the work environment as caused by individual faults, they felt there was little they could do to fix it. When employees found that differences between groups of employees made social support redundant or too difficult to do something about, the work environment and the quality of leadership was affected in a negative manner. Insufficient language skills could thus be seen as a system default instead of an individual problem.

One of the employees that changed jobs during the merger process tells how the nurses and doctors had changed their attitudes now that the person no longer was in the cleaning department:

The difference is respect and attitude at work. Because ... the nurses, doctors and managers, they look at me in a completely different way now that I am not a cleaner anymore; I am connected to them in another way because of the work tasks. Sometimes they need me now. Here, we work together. (E7, c, immigrant, good language skills) 
The strong status hierarchy of the hospital, the negative group thinking, and the tendency to devalue immigrant workers cannot be interpreted as a mere consequence of the restructuring process. It should be regarded as an organizational problem that increases when the level of employee insecurity has risen because of ongoing change processes. The management's lack of focus on these issues and strategies of avoidance will probably also have a stronger standing in a changing environment. Overall, these factors contribute to the making of what we call immigrant worker vulnerability.

\section{Manager availability: Participation and control over work}

In this section, we show how Saksvik and colleagues' $(2007,2009)$ category of manager availability must be extended or seen in relation to the importance of participation and control over work. Further, the original category should be highlighted as of mutual importance, both for employees and for lower level management. The need for adequate information at the right time and the opportunity for dialogues with superiors are closely linked to the experience of participation and thereby to control over work. This is as relevant to employees as it is to lower level management.

Part of the frustration that the employees experienced after moving into a new hospital relates to the lack of information and participation in the restructuring process in their respective units. However, frustration and anxiety among immigrant workers over the restructuring process is further compounded because of a lack of understanding of what is about to happen, and this may be attributed to inadequate language skills. A feeling of inadequacy, caused by limited access to information and few genuine possibilities to participate in the change processes, also holds for managers, as the following quote shows:

My manager put his head under his arm, and I had to solve all kinds of problems by myself. In addition to that, I had to run the department from day to day. I felt very inadequate! The night that we moved, something happened that I could not explain, we lost our wellbeing, social support and our work environment. I have had that feeling since then. No one likes it since that day. We are really struggling since then. (M1, can, Norwegian)

For the canteen workers, the changes are especially troublesome in the new hospital due to the implementation of new technology, new cash registers, and ultimately a new form of organizing work characterized by more rotation. The lack of training is also described as problematic. Because of this, the restructuring process is associated with a loss of control over work. One of the managers explains how the lack of control and any voice in the decision-making process and the implementation process poses challenges both for managers and for employees:

We got a modern canteen with new technology and a system that reaches far beyond our competence. Everyday life became very difficult for us...The cash register systems are so advanced that the employees are crying and refuse to work with them! We can manage to make food and to handle the dishwashers, but not the cash register! ... We have asked for training and courses repeatedly, but all we got was two afternoons of it. Now the service agreements are so expensive that I cannot afford to spend any money on it. Because of this, it has sort of turned into my problem as a manager. (M1, can, Norwegian) 
Another manager describes how a lack of information about some parts of the restructuring process made it impossible to inform the employees about coming changes:

\begin{abstract}
Eh, well, I would have liked to know more. I would really like to have had some more answers, so to speak. I need to start planning in detail now, but when the main strategy still is not there, it is difficult to start planning, when you do not know what to plan. For some of the employees there will be changes, but to them I have to say that I really do not know. (M9, sta, Norwegian)
\end{abstract}

To the majority of employees, the lack of established routines has been difficult to handle because their sense of control over work seems to have been affected in a negative manner. Even if change was anticipated, the feeling of uncertainty and distress has intensified over the course of time. Loss of control over work during organizational change has also been documented in several other studies (e.g., Kivimäki et al., 2000; Proctor and Dukakis, 2003; Worrall and Cooper, 1998).

For immigrant workers, again, there seems to be a slightly higher level of frustration, a feeling of loss of control over work, and a lack of access to management dialogue and participation in ongoing small change processes (e.g., the assignment and distribution of work).

\title{
Early role clarification: Role ambiguity among managers
}

Early role clarification reduces role stress by reducing role ambiguity and role conflict. Early role clarification is important because the consequences of role stress may be destructive for the change initiative, for the work group, and for the individual worker (Saksvik and Finne, 2009; Saksvik et al., 2007).

In our data, the category early role clarification turned out to be most relevant within the group of managers. We found little or no evidence that could suggest that a lack of early role clarification was a major stressor for either immigrant or nonimmigrant workers. One potential explanation for this is that the level of complexity in the jobs of low or unskilled employees is relatively low-they more or less perform the same type of work before, during, and after the main processes of change. In this sense, they are perhaps less susceptible to stress caused by role ambiguity and role conflict. The following quote illustrates this:

It is exciting to be a part of something brand new, something you can influence and form yourself. In many ways, it is ideal to be able to make your own position and things like that. But, when you feel that you hardly know anything about where to put your foot down and say, no, this is not my job, that is someone else's. (M12, can, Norwegian)

Middle managers are subjected to pressure from all sides when the vertical information flow is limited:

We (I) did not get sufficient information about the ongoing process-and my own manager had the same problem. There were never any answers to get. We had to hold off all the information by ourselves. There were not enough information meetings along the way- 
you can never get too much information and it is very important to be able to address what the employees wonder about, especially for the group of low skilled and unskilled employees. (M12, can, Norwegian)

In addition to this cross-pressure, several of the managers report that the process in itself was poorly planned and implemented in the sense that there was a lack of appropriate information about upcoming events. They felt that the time provided to plan for a new work organization and the training provided for newly appointed managers were insufficient. There were examples of managers that came from an employee position who had virtually no time to plan the work in their new job.

The uncertainty over how to organize the work in the new building, the role/position one is expected to fill, and how to manage the transition between the old and the new are described as confusing and difficult to handle by one of the newly appointed managers:

I used to work in this department before too, but at the same time I got this new position and was supposed to start preparing for what we did, something I did not know anything about. There were very few instructions about how the new section should be (...) and I did not have much time to spend because I was still working my old position. (M1, can, Norwegian)

For the line managers the perceived fact that there is no light at the end of the tunnel, so to speak, the sense of there being no answers to the ongoing questions of what is going to happen next, was frustrating. As one of them puts it: "When you have a question, very few know the answer. Everyone is going around saying I do not know what is happening, I do not know what is happening (M9, swa, Norwegian)."

We have now arrived at the part of our analysis that discusses the consequences of the restructuring process on the work environment, subjective health, and sick leave.

\section{Experienced results of the restructuring process}

\section{Increased time pressure and workload, negative outcome on work environment}

Changes in the psychosocial work environment associated with reorganizational processes like mergers and downsizing may in turn contribute to increased job strain or stress (Kivimäki et al., 2003; Korunka et al., 2003) and lay-off-survivor-syndrome (Noer, 1993).

Regardless of their ethnic origin, knowledge of the Norwegian language, or departmental affiliation, most employees and managers in the study reported an increase in workload, stress, and time pressure as a result of the restructuring process. Moreover, the restructuring process was perceived to have had a negative impact on both the physical and the psychosocial work environment.

Across the departments, many employees highlighted the size of the new hospital building, both in a positive and a more negative manner. To the cleaners, the workload had increased as a direct result of this, and they were consequently none too thrilled 
about it. One of the cleaners explained the consequences of the change and how the workers were made responsible for the increased workload:

The floor space is enormous! I do not think that anyone has figured out how big the difference is between now and before. And this difference must be taken care of by us... If one is not able to finish everything off in one day, the staff complains at once to the cleaning office. It was not like this in the old hospital. People used to talk to you then ... Now EVERYONE is stressed. No one has the time to give each other feedback. There is only complaining and yelling. (E14, c, Norwegian)

Their managers agree that both the workload and the time pressures have increased as a result of the restructuring process. One of them says: "There is no doubt that what we have is a new building with bright and nice surroundings, aesthetically pretty, but whether it has resulted in any real advantages for my people.. Well, I honestly do not know (M16, c, Norwegian)."

In the security and administration department, the increase in space meant more to keep an eye on, but this was not in itself regarded as problematic. The problem for the employees was that they had lost colleagues due to downsizing of the department. This had disillusioned them, depriving them of the joy of being in a better physical and esthetical environment and affecting their perception of the overall restructuring process in an adverse way. Workers, who remained after the downsizing, may in other words have suffered from some sort of lay-off-survivor-syndrome (Noer, 1993).

In the canteen department, the restructuring process had a negative outcome on the psychosocial work environment mainly because new equipment combined with too little focus on training and preparatory measures and other additional technical challenges made the work more straining in itself.

\section{Subjective health and sick leave}

Changes in the psychosocial work environment associated with reorganizational processes may also contribute to poorer self-reported health and sick leave (see, e.g., Bambra et al., 2007; Egan et al., 2007; Enehaug and Thune, 2007). Our material indicates that the restructuring process affects individual health in two ways. First, the uncertainty associated with partially new work content, and an increase in time pressure and workload (mostly for the cleaners) led to an experience of work as a more straining effort, and again, some symptoms of lay-off-survivor-syndrome (Noer, 1993):

We have gone through a lot in our job. We have moved to a larger hospital, we have a larger area and we have a lot more to do. However, there are personnel cuts and it is significant in our everyday lives that there is more to do and fewer people to do it. It is a heavy setback, in the main picture, that there is a lot of strain for the employees (...) a large proportion of the sick leave can be attributed to the fact that we are instructed to do more, without getting anything back, so to speak. We are just told to downsize and downsize. After all, we are responsible for the security of the hospital! In addition, I feel that this is not the way it should be, just because of money talk at higher levels. Finally, they do not even know what we are doing. This is how I feel. (E6, swa, Norwegian) 
Second, more strain brings about a sense of weariness and increases the likelihood that an employee will elect to stay home from work when he or she does not feel 100\% well. In other words, the short-term sickness absence (1-3 days) seems to be an individual way of coping. One of the employees, a woman who had been out for several short-term sickness absence periods, explains how her health was affected during the restructuring process:

It was tiring. I too felt exhausted. In the end, you feel sick as well. (...). I do believe that I have had some sickness absence because of this process. It is difficult to answer for the others. I am not the one to be that much sick, but what you notice is that what you attended work with earlier, is off limits now, because you are so tired to begin with that when you feel sick, you cannot get yourself going to work anymore. (E22, can, Norwegian)

One of the ethnic Norwegian cleaners considered her long-term sickness absence to be a direct result of her working conditions. She spoke of a workplace characterized by an increase in the workload and colleagues who were afraid to talk to their managers and too anxious about failing to fulfill their duties to take any breaks during work hours. The cleaner claims that: "No wonder there are so many on sick leave. Everyone has lost it! Several of my old colleagues have left with retirement pensions after sick leave! (E14, c, Norwegian)"

Additionally, there were also some indications of presenteeism among immigrant workers. Attending work while being ill themselves is highly common among physicians working at university hospitals (Sendén et al., 2013). Factors associated with a competitive climate and myths about a healthy doctor might contribute to this kind of behavior. We are not aware of studies analyzing the extent to which the culture of presenteeism among doctors at hospitals is passed on to nonmedical workers. Overcommitment among immigrants due to lower employment rates and higher unemployment risk (Saksvik and colleagues, 2010,2013) may be a competing or additional explanation for presenteeism among immigrant workers in our study. We see this as an interesting subject for further research, but conclude here that our empirical evidence is too weak to say anything certain about presenteeism of workers by immigrant status.

The restructuring process alone is not sufficient to explain the long-term sickness absence behavior reported by our informant workers.

\section{Conclusion}

We have analyzed qualitative interviews with 23 employees and 7 managers from the departments of cleaning, administration $\&$ security, and canteen in a major Norwegian hospital. The hospital has undergone major restructuring and mergers, including moving into a brand new building. We have examined whether the restructuring processes are experienced differently among 1) low/unskilled employees and their managers, 2) immigrant and nonimmigrant workers, and 3) immigrants with poor or good Norwegian language knowledge. We also speculate on the extent to which such differences influence the experience of the restructuring itself. By studying low or unskilled workers and their managers, we expand the literature on the effects of restructuring in hospitals. Prior studies of restructuring in hospitals have focused on high-skilled occupational groups 
such as doctors and nurses (e.g., Bernstrøm, 2014; Burke, 2002; Mamelund et al., 2014). We have framed our analysis within the dimensions of a healthy restructuring process as suggested by Saksvik and colleagues $(2007,2009)$, but have shown that it is useful to supplement the "manager availability dimension" by participation and control over work and to include social support as a self-contained dimension. Finally, we have investigated how the restructuring process affects the work environment, subjective health, and sickness absence of our informants.

Results show that the restructuring process is experienced as arbitrary when it comes to planning the changes, the sequence of events, and training. There is little or no involvement in the process for low or unskilled employees, and too little, too late in the process for most of their managers. Even if the managers have been more involved and informed about the ongoing restructuring processes than the employees, the managers express little sense of direct involvement and influence on the process and consequences of the process.

Even if most of our informants in one way or the other appreciated the new hospital venues, most of them experienced an increase in workload, time pressure, and stress, and a decrease in well-being, autonomy, and social support, with respect to both managers and their fellow colleagues. Some of the managers have experienced a significant rise in administrative tasks, partly due to an increase in personnel responsibilities. Having responsibility for between 40 and 60 employees gave them fewer opportunities for follow-up on a regular basis. Even when managers knew what did not work, for example, a lack of social support, too heavy a workload, or insufficient communication, they tended to do little if anything about the situation. This was probably due to a lack of resources, as well as they themselves having too much to do. The fact that communication channels and cooperation with higher-level managers had not found its form as of yet did not help the situation.

The domino effect on cleaners and canteen employees. Restructuring processes that last for several years seem to have boosted feelings of insecurity among employees regarding role clarification and triggered stress throughout the organization. Together with heavier workloads and new tasks this gave cleaners and canteen employees the feeling that "all bad things will eventually be attributed to them," including any increase in sick leaves. Our data cannot say if there is a causal effect from this state of affairs to sick leave, or separate causation from selection, but there is a plausible connection between stress and sick leave and we therefore assume that these factors may be connected throughout. Our results are nevertheless in accordance with prior quantitative research on the association between reorganization and sick leave listing (Bernstrøm, 2014; Mamelund et al., 2014). It is also on par with other research showing that a climate of constant change is a major source of dissatisfaction for many employees (McHugh, 1997).

Our study further suggests that immigrant employees have experienced a greater loss of control over work, and a larger decrease in well-being, autonomy, and social support both from managers and from colleagues than their nonimmigrant colleagues have. Among the immigrants, those with a poor understanding of the Norwegian language were worse off than those with a better language proficiency. Immigrants also reported less understanding of the implications of the process and participated less in the organization's knowledge-sharing communities in the organization than nonimmigrants. Regardless of department affiliation, immigrant status, and knowledge of the Norwegian language, we also found that most of the workers experienced an increase in workload, 
time pressure, strain, and stress. It is also plausible that the restructuring was associated with a higher level of both short-term sick leaves and presenteeism. However, we could not document any differences across immigrant status in these two outcomes.

Even when work demands little or no communication skills on a day-to-day basis, insufficient Norwegian language skills should be considered an overall challenge, not only for immigrant workers themselves but also for their colleagues and for the leadership. We have shown that major restructuring or restructuring processes increase issues of communication and the experience of stress and a poor work environment. This finding is also in line with prior research (Enehaug, 2008; Enehaug and Widding, 2011, 2013) which suggests that improved communication skills and an improvement of diversity management skills could be significant in preventing undesirable effects out of the ordinary for low and unskilled workers of all origins during the restructuring of organizations. Workers' loss of control over work and their lack of access to information and management resources put a strain on the individual and have an adverse impact on the opportunity for social support during the restructuring process. These factors also seem to play an important role in explaining a deteriorated work environment for lower level managers. Immigrant workers tend to be associated with a negative work environment because of an assumed lack of knowledge, both when it comes to language and a sufficient understanding or awareness of local norms and general work life norms. The ethnic differences documented in our analysis-even by level of understanding of the Norwegian language-is smaller than we initially expected. We suggest that this is due to a strong occupational hierarchy within the hospital, and that this has an overall influence on low and unskilled employees' position in, perception of, and involvement in the restructuring process.

\section{Acknowledgments}

This research project is part of a larger project: "Reorganizing the specialist health services: What are the consequences for the individual employees," which is a part of The Norwegian Research Council's Sickness Absence Program Initiative. Financial support from the Norwegian Research Council (grant 193614) is gratefully acknowledged.

Dr. med. Migle Gamperiene participated in the design of the research project and the data collection. She also contributed to an early version of this article.

\section{References}

Armenakis AA and Bedeian AG. (1999) Organizational change: a review of theory and research in the 1990s. Journal of Management 25: 293-315.

Balzer M, Westerlund H, Backhans M, et al. (2011) Involvement and structure: a qualitative study of organizational change and sickness absence among women in the public sector in Sweden. BMC Public Health 11: 1-17.

Bambra C, Egan M, Thomas S, et al. (2007) The psychosocial and health effects of workplace reorganisation. 2. A systematic review of task restructuring interventions. Journal of Epidemiology and Community Health 61: 1028-1037.

Berg B. (2000) Mangfold: om rekruttering og integrering av innvandrere $i$ statlige virksomheter (Diversity: about the recruitment and integration of immigrants in governmental businesses). Trondheim: SINTEF IFIM. 
Berg B, Annfelt T and Vedi C. (1999) Ny ved [i.e. vev] i gammel renning: samarbeid om kvalifisering for flyktninger og innvandrere (New logs in old timber passes. Cooperation for the qualification of refugees and immigrants). Trondheim: SINTEF IFIM.

Bernstrøm VH. (2014) Organizational Changes and Sickness Absence in Norwegian Hospitals. Faculty of Medicine. Oslo: University of Oslo.

Burke RJ. (2002) Work experiences and psychological well-being of former hospital-bases nurses now employed elsewhere. Psychological Reports 91: 1059-1064.

Creswell JW. (2013) Qualitative Inquiry \& Research Design. Choosing Among Five Approaches. Los Angeles: Sage.

Dahl-Jørgensen C and Saksvik PØ. (2005) An evaluation of the impact of two workplace interventions on the health of service workers. International Journal of Health Services 35: 529-549.

DeWitte H. (1999) Job insecurity and psychological well-being: review of the literature and exploration of some unresolved issues. European Journal of Work and Organizational Psychology 8: 155-177.

Egan M, Bambra C, Thomas S, et al. (2007) The psychosocial and health effects of workplace reorganisation. 1. A systematic review of organisational-level interventions that aim to increase employee control. Journal of Epidemiology and Community Health 61: 945-954.

Enehaug H, Gamperiene M, Hetle A, et al. (2008) Arbeidsmiljø og helse i renholdsbransjen: sluttrapport (Work Environment and Health in the Cleaning Industry). Oslo: Arbeidsforskningsinstituttet.

Enehaug $\mathrm{H}$ and Thune T. (2007) Organisasjonskultur og mennesker i fusjonsprosesser (Organizational Culture and People in Mergers and Acquisitions). Oslo: Arbeidsforskningsinstituttet.

Enehaug H and Widding S. (2011) Kompetanse, oppleering og mangfold (Competence, Training and Diversity). Oslo: Arbeidsforskningsinstituttet.

Enehaug H and Widding S. (2013) Evaluering av prosjektet "Godt nok norsk": et opploeringsprosjekt for minoritetsspråklig helsepersonell i den kommunale pleie- og omsorgstjeneste (Evaluation of the project «Sufficient Norwegian»: a traning project for immigrant health workers in the communal health service). Oslo: Arbeidsforskningsinstituttet.

Farsethås HC, Johnsen KH and Venneslan K. (2011) Arbeidsmiljø for innvandrere på flerkulturelle arbeidsplasser (The Work Environment of Immigrants in Multicultural Work Places). Sluttrapport til Nordisk Ministerråd. Bergen: Universitetet i Bergen.

Gamperiene M. (2008) Health and work environment among women in unskilled occupations. Oslo: Unipub, 1 b. (flere pag.).

Grambo A-C and Myklebø S. (2010) Tidligere NAV-brukere-hva gjør de nå? (Former users of welfare benefits-what are they doing now?). Arbeid og Velferd: 25-37.

Håpnes T and Iversen A. (2000) "Jeg fant, jeg fant!-": gode strategier i flerkulturelle bedrifter ("I Found, I Found!": Good Strategies in Multicultural Companies). Trondheim: SINTEF IFIM.

Johansen R and Østby M. (1998) Arbeid og laering for arbeidsledige fremmedspråklige: evaluering av ALFA-prosjektet (Work and Learning for Unemployed Foreign Language Speakers: Evaluating the ALFA-project). Oslo: Arbeidsforskningsinstituttet.

Karasek R and Theorell T. (1990) Healthy Work: Stress, Productivity, and the Reconstruction of Working Life. New York: Basic Books.

Kivimäki M, Vahtera J, Elovainio M, et al. (2003) Human costs of organizational downsizing: comparing health trends between leavers and stayers. American Journal of Community Psychology 32: 57-67.

Kivimäki M, Vahtera J, Pentti J, et al. (2000) Factors underlying the effect of organisational downsizing on health of employees: a longitudinal cohort study. British Medical Journal 320: 971-975. 
Korunka C, Scharitzer D, Carayon P, et al. (2003) Employee strain and job satisfaction related to an implementation of quality in a public service organization: a longitudinal study. Work \& Stress 17: 52-72.

Kvale S and Brinkmann S. (2009) Det kvalitative forskningsintervju (The Qualitative Research Interview). Oslo: Gyldendal akademisk.

Llorens S, Bakker AB, Schaufeli W, et al. (2006) Testing the robustness of the job demandsresources model. International Journal of Stress Management 13: 378-391.

Mamelund S-E, Ingelsrud MH and Reneflot A. (2014) Marital status as a moderator of the association between reorganization and sickness absence. Manuscript.

Marshall C and Rossman GB. (1989) Designing Qualitative Research. Newbury Park, CA: Sage Publications.

McHugh M. (1997) The stress factor: another item for the change management agenda? Journal of Organizational Change Management 10: 345-362.

Noer DM. (1993) Healing the Wounds: Overcoming the Trauma of Layoffs and Revitalizing Downsized Organizations. San Francisco: Jossey-Bass.

Nytrø K, Saksvik PØ, Mikkelsen A, et al. (2000) An appraisal of key factors in the implementation of occupational stress interventions. Work \& Stress 14: 213-225.

Patton MQ. (1990) Qualitative Evaluation and Research Methods. Newbury Park, CA: Sage.

Patton MQ. (2002) Qualitative Research \& Evaluation Methods. California: Sage Publications.

Proctor T and Dukakis I. (2003) Change management: the role of internal communication and employee development. Corporate Communications 8: 268-276.

Randall R, Nielsen K and Tvedt SD. (2009) The development of five scales to measure employees' appraisals of organizational-level stress management interventions. Work \& Stress: An International Journal of Work, Health and Organisations 23: 1-23.

Ravasi D and Schultz M. (2006) Responding to organizational identity threats: exploring the role of organizational culture. Academy of Management Journal 49: 433-458.

Rogstad J. (1998) Innvandrere og arbeid: en empirisk studie $i$ fire bedrifter (Immigrants and Work: An Empirical Study in Four Companies). Oslo: Institutt for samfunnsforskning.

Rogstad J. (2000) Mellom faktiske og forestilte forskjeller: synlige minoriteter på arbeidsmarkedet (Between Real and Imagined Differences: Visible Minorities at the Labour Market). Oslo: Institutt for samfunnsforskning, $310 \mathrm{~s}$.

Rogstad J and Raaum O. (1997) Utstøting fra arbeidsmarkedet blant arbeidstakere med innvandrerbakgrunn (Exclusion from the Labour Market Among Immigrant Employees). Bergen: SNF.

Saksvik PØ and Finne LB. (2009) Mestring av endring i arbeidslivet (The Mastery of Change in Work Life). Klinisk organisasjonspsykologi. [Oslo]: Cappelen akademisk, S. [277]-292.

Saksvik PØ, Nytrø K, Dahl-Jørgensen C, et al. (2002) A process evaluation of individual and organizational occupational stress and health interventions. Work \& Stress 16: 37-57.

Saksvik PØ, Tvedt SD, Nytrø K, et al. (2007) Developing criteria for healthy organizational change. Work \& Stress 21: 243-263.

Saksvik P-Ø, Dahl-Jørgensen C, Tvedt SD, et al. (2010) Identity, over-commitment, work environment, and health outcomes among immigrant workers. Journal of Identity and Migration Studies 4: 2-22.

Saksvik PØ, Dahl-Jørgensen C and Tvedt SD. (2013) Migrant labor in the workforce. Journal of Identity and Migration Studies 7: 95-110.

Savin-Baden M and Major CH. (2013) Qualitative Research: The Essential Guide to Theory and Practice. London: Routledge.

Schabracq MJ, Cooper CL and Winnubst JAM. (2003) Introduction. In: Schabracq MJ, Winnubst JAM and Cooper CL (eds) The Handbook of Work \& Health Psychology. Second ed. West Sussex: John Wiley \& Sons, 1-6. 
Schweiger D and DeNisi A. (1991) Communicating with employees following a merger: a longitudinal field experiment. Academy of Management Journal 34: 110-135.

Self DR, Armenakis AA and Schraeder M. (2007) Organizational change, content, process, and context: a simultaneous analysis of employee reactions. Journal of Change Management 7: 211-229.

Sendén MG, Løvseth LT, Schenck-Gustafsson K, et al. (2013) What makes physicians go to work while sick: a comparative study of sickness presenteeism in four European countries (HOUPE). Swiss Med Wkly 201.

Trygstad SC. (2006) Den Nye staten: omfang og effekter av omstillingene i staten 1990-2004 (The new State: the range and effects of restructuring processes in the State 1990-2004). Oslo: Fafo.

Van Knippenberg B, Martin L and Tyler T. (2006) Process-orientation versus outcomeorientation during organizational change: the role of organizational identification. Journal of Organizational Behavior 27: 685-704.

Whetten DA. (2006) Albert and Whetten revisited: strengthening the concept of organizational identity. Journal of Management Inquiry 15: 219-234.

Worrall L and Cooper CL. (1998) Quality of Working Life Survey of Managers' Changing Experiences. London: Institute of Management. 